\title{
PENGINTEGRASIAN PERENCANAAN SUMBERDAYA MANUSIA DAN STRATEGI ORGANISASIONAL : CATATAN KECIL
}

\section{Majang Palupi ${ }^{1}$, Heru Kurnianto Tjahjono ${ }^{2}$}

\author{
${ }^{1}$ Universitas Islam Indonesia \\ Majang_palupi@uii.ac.id \\ ${ }^{2}$ Universitas Muhammadiyah Yogyakarta \\ herukurnianto@umy.ac.id
}

\begin{abstract}
This study is short review and critical note of author on the article integrating HR planning and organizational strategy written Simon S.K. Lam \& John Schaubroeck (1998). The author has discussed and written critical note related concepts, practices and methods on their article. Note in this article explained that the integration of human resources planning and organizational strategy play an important role in explaining organizational performance, but contextual aspects should be considered.
\end{abstract}

Keywords: human resource planning, organizational strategy, organizational performance

(C) 2018 JBTI. All rights reserved

Article history : received 26 Des 2017; revised 5 Jan 2018 ; accepted 15 Jan 2018

\section{PENDAHULUAN}

Tuntutan kompetisi pasar telah memberikan tekanan yang belum pernah terjadi sebelumnya terhadap organisasi untuk menemukan cara yang lebih efisien dalam operasionalnya dan lebih responsif terhadap kebutuhan pelanggan. Manajemen sumberdaya manusia (SDM) dipandang sebagai suatu kunci untuk mengembangkan dan mengimplementasikan respon strategik akan tekanan tersebut. Para ahli dan praktisi dan berpendapat bahwa pengencangan hubungan antara MSDM dan strategi organisasi menjadi sangat penting untuk kelangsungan organisasi dalam persaingan. Para profesional SDM didorong untuk mengaitkan usaha mereka dengan proses perencanaan strategik (strategic planning process) sehingga dapat tercipta suatu kemitraan strategik dengan manajer lini organisasi. Sebagai akibat dari kemitraan ini maka praktik-praktik manajemen SDM akan secara signifikan sesuai dengan tujuan strategik yang menyeluruh.

Namun demikian, masih sangat sedikit penelitian empiris yang telah dilakukan untuk menentukan bagaimana perencanaan sumberdaya manusia berhubungan dengan kinerja telah dilakukan oleh organisasi. Demikian juga belum banyak diketahui bagaimana proses perencanaan sumberdaya manusia dikombinasikan dengan tujuannya untuk berintegrasi dengan strategi organisasi. Sejumlah studi dewasa ini, fokus dari perencanaan sumberdaya manusia - yaitu perencanaan untuk mencapai tujuan - dan bagaimana perencanaan dilaksanakan, diperlukan secara independen dalam literatur yang ada. Oleh karena itu penelitian ini bertujuan untuk memahami lebih mendalam tentang bagaimana tujuan perencanaan sumberdaya manusia dan tingkat formalitas dari proses perencanaan sumberdaya manusia secara bersama berperan menentukan peran kebermanfaatan Manajemen SDM bagi keefektifan strategi dan peningkatan kinerja organisasional. Banyak studi terdahulu telah menunjukkan bahwa praktik-praktik manajemen SDM seperti perencanaan sumberdaya manusia memiliki peran penting pada kinerja organisasional (Huselid,1995; Nkomo, 1987). Studi ini menyusun kajian yang lebih spesifik dan bersifat interaktif 
antara formalisasi perencanaan sumberdaya manusia dan kejelasan tujuan perencanaan sumberdaya manusia.

Dalam studi ini langkah pertama dilakukan adalah mengidentifikasi bagaimana kecenderungan organisasi dalam membuat perencanaan sumberdaya manusia. Bagaimana tujuan perencanaan sumberdaya manusia berkontribusi dalam mencapai tujuan organisasi. Ini dilakukan dengan diskusi mengenai tujuan-tujuan perencanaan sumberdaya manusia dan dilanjutkan dengan klarifikasi tujuan dan formalitas proses perencanaan sumberdaya manusia itu sendiri. Langkah kedua adalah menguji bagaimana tujuan-tujuan perencanaan berkontribusi terhadap manfaat perencanaan sumberdaya manusia yang dirasakan terhadap pencapaian tujuan organisasi. Ketiga, studi ini kemudian menguji peran formalitas proses perencanaan sumberdaya manusia sebagai suatu moderator potensial dari hubungan antara tujuan perencanaan sumberdaya manusia dan impaknya.

\section{METODE PENELITIAN}

Studi ini menggunakan sampel yang terdiri dari dua kelompok, manajer sumberdaya manusia senior dan menengah, dari perusahaan-perusahaan dalam lima industri yang berbeda, dengan tingkat penjualan per tahun berkisar dari $\$ 4,3$ juta US dengan hanya 38 karyawan hingga $\$ 45,2$ juta US dengan karyawan berjumlah 841 orang, yang hadir dalam suatu seminar perencanaan SDM di Hongkong, yang dilakukan dua kali dengan jeda waktu enam bulan. Seminar pertama dihadiri 41 manajer, sedang yang kedua 44 manajer, sehingga total berjumlah 85 orang sampel.

Interview yang semi-struktur dilakukan dalam kelompok yang terdiri 6 manajer selama dua hari seminar. Pertama responden diberi pertanyaan tentang (1) gambaran tujuan utama dalam melakukan perencanaan sumberdaya manusia dalam organisasi masing-masing dan keterlibatannya dalam proses tersebut, (2) gambaran singkat langkah-langkah penting yang dilakukan atau menyebutkan pendekatan yang dilakukan. Selanjutnya responden diminta untuk mengisi dua kuesioner: (1) terdiri dari dua bagian - (1.a) "kejelasan tujuan perencanaan" yang mengukur seberapa jelas tujuan perencanaan SDM yang diadopsi perusahaan, dan (1.b) "proses perencanaan" yang menguji formalitasnya; (2) informasi kinerja perencanaan SDM pada masing-masing perusahaan, yang pada awalnya dikirim kepada CEO, meski lebih dari separuh respon diperoleh dari kepala operasional atau direktur perencanaan.

\section{Analisis}

Perencanaan sumberdaya manusia adalah salah satu dari sejumlah praktik-praktik manajemen sumberdaya manusia yang memiliki peran meningkatkan kinerja organisasional. Dalam artikel Lam dan Schrubroeck (1998), data yang ada dianalisis dalam tiga fase: (1) menetapkan serangkaian orientasi tujuan perencanaan SDM dari berbagai sampel perusahaan, (2) menguji perbedaan kinerja perencanaan SDM yang dirasakan pada berbagai orientasi tujuan yang berbeda, (3) menguji efek bersama (joint effects) dari formalitas proses perencanaan dan tujuan perencanaan SDM pada kinerja kemanfaatan secara organisasional.

\section{Hasil dan Diskusi}

Hasil penelitian ini menunjukkan rerangka yang menghubungkan formalisasi perencanaan sumberdaya manusia dan tujuan perencanaan dengan kegunaan organisasional dari perencanaan sumberdaya manusia, seperti terangkum pada Gambar 1. "Formalisasi perencanaan" merepresentasikan derajat sejauh mana proses perencanaan sumberdaya manusia eksplisit dan dikodifikasikan pada tiga level, sementara derajat "kejelasan tujuan perencanaan" menekankan pada 
kejelasan masing-masing orientasi tujuan. Saat perusahaan dalam studi ini diklasifikasikan ke dalam dua dimensi yang ada, maka muncul suatu pola kinerja yang sistematik.

Gambar 1. Formalisasi dan Tujuan Perencanaan sumberdaya manusia

PLANNING FORMALISATION

\begin{tabular}{|c|c|c|c|}
\hline \multirow{3}{*}{ 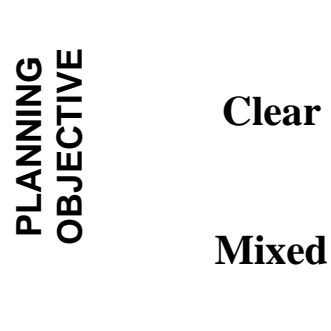 } & High & Moderate & Low \\
\hline & High Performance & High Performance & $\begin{array}{c}\text { Average } \\
\text { Performance }\end{array}$ \\
\hline & High Performance & $\begin{array}{c}\text { Average } \\
\text { Performance }\end{array}$ & Low Performance \\
\hline $\begin{array}{l}\text { Not } \\
\text { Clear }\end{array}$ & High Performance & Low Performance & Low Performance \\
\hline
\end{tabular}

Gambar 1 menunjukkan bahwa proses formalisasi perencanaan sumberdaya manusia yang tinggi menjadi penentu penting kinerja organisasional tinggi meskipun kejelasan tujuan perencanaan sumberdaya manusia pada berbagai level jelas bahkan tidak jelas.

Dengan meningkatnya formalisasi perencanaan sumberdaya manusia, maka meningkat pula kinerja sumberdaya manusia di dalam organisasi. Apabila formalisasi perencanaan sumberdaya manusia menurun baik pada level moderat sampai dengan rendah berdampak pada penurunan kinerja organisasional. Akan tetapi, pada level formalisasi perencanaan yang moderat dan rendah berinteraksi dengan kejelasan tujuan perencanaan. Sebagai contoh formalisasi perencanaan yang moderat masih dapat meningkatkan kinerja yang tinggi apabila kejelasan tujuan perencanaan tinggi. Demikian pula kejelasan tujuan perencanaan dapat mengkompensasi rendahnya formalisasi perencanaan untuk menghindari kinerja organisasional yang rendah.

Dari aspek kejelasan tujuan perencanaan sumberdaya manusia yang tinggi akan berdampak pada manfaat dan kinerja organisasional yang tinggi, kecuali apabila berinteraksi dengan formalisasi perencanaan sumberdaya manusia yang rendah. Interaksinya berdampak pada kinerja rata-rata. Ketidakjelasan tujuan perencanaan sumberdaya manusia secara umum berdampak pada penurunan kinerja organisasional. Namun sensitifitasnya tidak lebih tinggi daripada sensitifitas formalisasi perencanaan sumberdaya manusia. Hal ini tampak pada naik turunnya formalisasi perencanaan sumberdaya manusia saat berinteraksi dengan kejelasan tujuan perencanaan sumberdaya manusia hampir selalu sensitif berdampak pada naik turunnya level kinerja organisasional.

Penelitian ini dari sisi metode menjadi bahan diskusi menarik. Diskusi menarik tersebut di antaranya apakah peryataan tersebut bersifat universal lintas populasi ataukah bersifat kontekstual, bagaimana cara mengukur formalisasi perencaan dan kejelasan tujuan perencanaan.Perbedaan lintas populasi berkaitan dengan perbedaan subjek atau individu. Sedangkan pengukuran terkait dengan seberapa presisi alat dalam menggambarkan konsep yang diukur.

Sejumlah studi menunjukkan peran perspektif kontingensi dalam model praktik-praktik manajemen SDM dalam meningkatkan kinerja (Delery \& Doty, 1996; Tjahjono, 2005; Palupi, 2017). Hasil di atas menunjukkan perspektif kontingensi memiliki peran memahami kegunaan perencanaan SDM. Suatu tujuan perencanaan yang jelas dan tunggal menjadi sebuah faktor yang penting dianggap sebagai kontribusi yang signifikan terhadap kinerja suatu organisasi, walaupun formalisasi perencanaan yang dilakukan perusahaan rendah. Hal tersebut mengandung makna 
bahwa proses perencanaan yang tidak eksplisit dapat berbanding terbalik dengan kinerja organisasonal, sedangkan suatu pendekatan perencanaan SDM yang terfokus-secara baik berperan meningkatkan kinerja organisasional.

Mengapa proses formalisasi perencanaan sumberdaya manusia menjadi penting? Proses formalisasi perencanaan cenderung lebih sistematis mengatasi berbagai kesenjangan dan banyak variasi dalam pemanfaatan SDM, sehingga menjadi lebih baik dalam menerjemahkan data ke dalam evaluasi kompetensi inti yang sangat penting untuk mendefinisikan orientasi strategik perusahaan ke hal yang lebih operasional. Dengan demikian formalisasi sumberdaya manusia dapat mengurangi variasi-variasi yang tidak produktif bagi peningkatan kinerja organisasional, bahkan dapat meningkatkan sinergitas di dalam proses organisasional.

Sebagian besar perencanaan sumberdaya manusia di Hongkong masih fokus pada operasional dan pengawasan, yang artinya masih sangat diperlukan sosialisasi dan pendidikan yang lebih luas pada tingkat manajemen untuk menyebarluaskan pengetahuan dan pemahaman tentang perencanaan yang secara strategik terfokus dan manfaatnya. Data juga menunjukkan bahwa baik formalisasi perencanaan sumberdaya manusia dan kejelasan tujuan perencanaan sumberdaya manusia menjadi hal penting bagi pencapaian kinerja organisasional. Penelitian ini menunjukkan bahwa tujuan yang jelas sangat dibutuhkan untuk kegunaan perencanaan sumberdaya manusia dan membuat proses eksplisit dan dikodifikasi menjadi penting dengan meningkatnya range tujuan perencanaan. Perencanaan sumberdaya manusia tidak hanya memerlukan teknik yang baik, namun juga kemampuan dalam menerapkannya.

Sampel dalam penelitian ini cukup baik untuk menjelaskan industri-industri tertentu di Hongkong, namun pertimbangan kontekstual menjadi penting mengingat kemampuan generalisasi sampel dalam penelitian relatif terbatas. Hal ini semakin penting apabila penelitian dilakukan pada negara yang berbeda denga latar belakang yang berbeda. Demikian pula karakteristik perusahaan seperti perusahaan yang masuk kategorisasi UMKM, start up dan lain-lain perlu kajian yang kontekstual. Aspek-aspek perbedaan subjektif individu lintas generasi seperti kehadiran generasi millennial saat ini dapat membedakan sejumlah hasil penelitian.

Demikian pula banyak perspektif untuk melihat strategi sehingga dalam kaitannya dengan pengintegrasian strategi dan perencanaan, maka persepektif lain seperti budaya dan pembelajaran organisasional dapat dipertimbangkan (Tjahjono, 2004). Dalam perspektif budaya terkait dengan nilai-nilai subjek atau individu penelitian. Sedangkan dari perspektif pembelajaran menunjukkan adanya proses yang bersifat dinamik.

\section{Catatan Kecil}

1. Integrasi perencanaan sumberdaya manusia dan strategi organisasi semakin kritikal dalam upaya peningkatan kinerja organisasional.

2. Di dalam pengintegrasian perencanaan sumberdaya manusia dan strategi organisasi, hubungan antara formalisasi perencanaan sumberdaya manusia dan kejelasan tujuan perencanaan sumberdaya manusia dengan kinerja berperan kritikal. Sensitifitas keduanya, baik formalisasi perencanaan sumberdaya manusia dan kejelasan tujuan perencanaan sumberdaya manusia bersifat unik.

3. Perspektif kontinjensi penting dipertimbangkan dalam praktik-praktik manajemen sumberdaya manusia, dalam hal ini spesifik padaperencanaan sumberdaya manusia dan kejelasan tujuan perencanaan sumberdaya manusia untuk peningkatan kinerja organisasional.

4. Dalam studi ke depan penting mempertimbangkan aspek kontekstual mengingat keterbatasan sampel dalam penelitian ini. Aspek kontkestual dan keterbatasan sampel berhubungan dengan keberagaman subjek yang sesungguhnya. 
5. Dalam integrasi strategi dan perencanaan sumberdaya manusia penting memperkaya perspektif strategi dan pembelajaran sehingga kajian studi menjadi lebih komprehensif.

\section{DAFTAR PUSTAKA}

Delery, J. E., \& Doty, D. H. (1996). Modes of theorizing in strategic human resource management: Tests of universalistic, contingency. Academy of Management Journal, 39(4), 802-835.

Huselid, M.A. (1995). The impact of human resource management practices on turnover, productivity and corporate financial performance. Academy of Management Journal, 38: 635-672.

Lam, S.S.K. \& Schaubroeck (1998), J. Integrating HR planning and organizational strategy. Human Resource Management Journal, 8(3): 5-19.

Nkomo, S.M. (1987). Human resource planning and organizational performance: an exploratory analysis. Strategic Management Journal, 8: 387-392.

Palupi, M, (2017). Catatan studi evolusi manajemen sumberdaya manusia strategik. Jurnal Bisnis teori dan Implementasi, 9(2):190-199.

Tjahjono, H.K. (2004). Strategi: tinjauan aspek modal sosial dalam cultural school dan learning school. Jurnal Manajemen dan Bisnis Utilitas,12(2):107-119.

Tjahjono, H.K. (2005). Praktik-praktik manajemen SDM strategik: pengujian universalistik dan kontinjensi dalam menjelaskan kinerja organisasional. Jurnal Bisnis dan Ekonomi Kinerja, 9(2): 123-134.

Ulrich, D. (1992). Strategic and human resource planning:lingking customers and employees. Human Resource Planning, 15(2): 47-62. 